\title{
CONSIDERAÇÕES PRELIMINARES SÔBRE A GEOLOGIA DO BATOLITO DA BAIXA VERDE - PERNAMBUCO
}

Dissertação de Mestrado apresentada

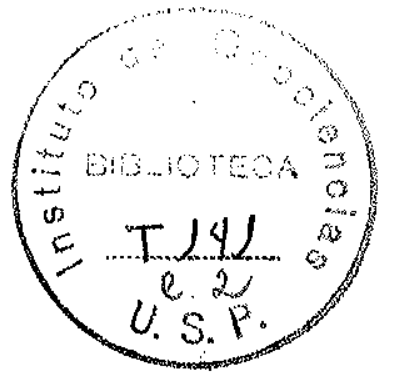
ao Instituto de Geociências da Universidade de São Paulo

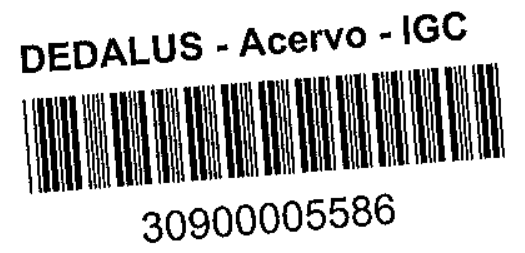




\section{INDICE DE ASSUNTOS}

pag.

RESUMO $\ldots \ldots \ldots \ldots \ldots \ldots \ldots \ldots \ldots \ldots \ldots \ldots \ldots \ldots \ldots \ldots$

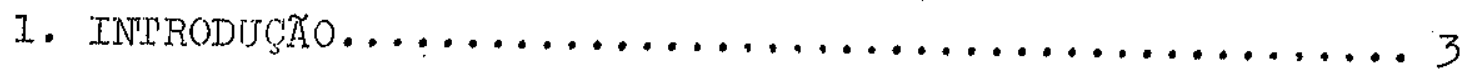

2. GEOMORTOTOMTA.......................

3. GEOLOGIA REGIONAI,

3.1. lectônica....................... 5

3.2. Estratigrafia.....................

4. GEOLOGIA DO MACICO ALCAIIINO

4.1. Relą̧ós de Contato..................... . . .

4.2. Litologia

4.2.7. Generalidades......................6

4.2.2. Micaxistos....................... . .

4.2.3. Gnajsses de transição..............19

4.2 .4$. sienitos........................20

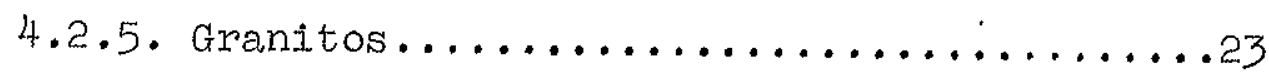

4.2 .6$. Discissão.....................23

4.3. Estruturas

4.3.1. Generalidades.....................24

4.3.2. Xistosidade e dobramentos.............24

4.3.3. Estruturas do plúton................25

4.3 .4$. Pathas.........................27 
5. DEFINIÇÃO DO CARÁTER INTRUSIVO E

CTASSTITCAMO TECTONTCA DO MACTCO

5.1. Caráter Intrusivo...................28

5.2. Classificação Tectônica..................28

6. CONSIDERACYOES FINAIS E CONCIUSOES

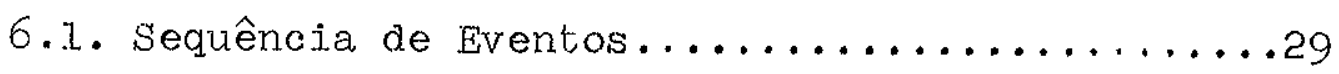

BIBIIOGRAFIA ........................ . . : 32

AGRADECIMENTOS . . . . . . . . . . . . . . . . . . . 34

ANEXXOS :

Fotografias

Microfotografias

Mapa Geológicc

Secção Geológicaa $A B$

Secção Geológrica CD

Tabela de Composições Modais 


\section{RESUMO}

O macico alcalino da Serra da Baixa Verde abrange uma área de exposição de aproximadamente $400 \mathrm{~km}^{2}$ e $10 c a 1 i z a-s e$ na dị Visa entre os Estados de Paraíba e Pernambuco, no Nordeste brasi leiro. Do ponto de vista geológico encon'tra-se incluido na chama da "zona transversal" de EBERT (1958), constituída por rochas predominantemente pré-cambrianas, delimitada ao sul pelo linea mento de pernambuco e ao Norte pelo de Patos ou Paraíba.

Petrográficamente, trata-se de uma intrusiva ígnea clas sificada como quartzo augita sienito, podendo ser considerada co mo uma diferenciação menos ácida de um magma granítico encontrado na região e localmente situado na parte leste da área estudada. Suas relações de contato são geralmente concordantes e par cialmente discordantes com as estruturas encaixantes e, tal fato, ligado a outras evidências, levou-nos a supor uma origem tarditec tônica para o maciço. Do ponto de vista estratigráfico, as rochas encaixantes são metamórficas pertencentes aos Grupos Uauá e Cacho eirinha (BARBOSA et al, 1970), de jdades pré-cambriano inferior e superior, respectivamente. Estes dois Grupos são constituídos localmente por micaxistos gnaissificados e fenitizados nas bordas da intrusão e dobrados aproximadamente na direção EW-NE. O maciço apresentamse cortado por falhas de natureza transcorrente, chegan do algumas a medir mais de $25 \mathrm{~km}$ de comprimento. Estas feições dismuptivas estão associadas na sua majoria aos lineamentos de Pa tos e Pernambuco. 
A țdade do sienjto supõe-se que seja de aproximadamente 500 milhões de anos, em analogia com datações K-Ar efetuadas em corpos similares. O autor acredita que esta ígnea constituj parte de um conjunto de corpos sienito-graníticos introduzidos tarditec tonicamente durante o Eo Cambriano. 


\section{INTRODUCAO}

o trabalho em questão visa apenas a caracterização estru tural e petrográfica preliminar do maciço alcalino da serra da Bai xa Verde. Tal macico faz parte do alto divisor dos Estados de Pernambuco e Paraíba, entre Triunfo e Sta. Izabel. Por ocasião dos trabalhos de campo não tinha sido publicado ainda o boletjm n. 140 do DNPM referente a Projeto Cobre, que inclui a geologia da área estudada dentro de um esquema mais genérico ligado aos problemas de Geologia Econômica da Região do Médio São Francisco.

A metodologia de traballho utilitiada baseou-se no exame de fotografias aéreas e mosaicos e contrôle de campo por meio de levantamentos geológicos ao longo de perfís com coleta de amostras de rocha e sol.o. As rochas coletadas foram examinadas em lâminas, sob o microscópio petrográfico, tendo sido efetuadas análises da distribuição modal de minerais componentes pelo método de contagem de pontos de Chayes (1949).

\section{GEOMOREOLOGIA}

A Serra da Baixa Verde encontra se incluida no cruzamento de dois grandes eixos montanhosos, localmente com direções $N$ E e EW. O primeiro passa por Arapuã, Umã e Princeza Izabel e o segundo provém de Sento sé na Bahia assumindo direção EW ao sult de Araripe. Estes eixos se destacam em relêvo na topografia arrasada da região. No topo da Serra da Baixa Verde está representada uma porcão reliquiar da mais antiga superfície de erosão conhecida na 
região, com altitudes oscilando entre 1000 e $1100 \mathrm{~m}$ e demominada "Superfície Pós-Gondwana" por KTING (1956). Os flancos da Serra são relativamente abruptos, (vide foto ns 1) o que está Iigado a efeitos de erosão diferencial e condicionamentos tercônicos. Tal aspecto contrasta sobremaneira com a superfície suave de erosão dos terrenos xistosos das vizinhanças denominadas "Soledade" por MEUNIER (1961) e com altitcudes oscilando entre 500 e $600 \mathrm{~m}$.

A drenagem encontra-se fortemente condicionada pelas estruturas geológicas. o principal rio da região, o rio pajeú, que é afluente do São Francisco, corre em geral paralelamente a xistcosidade havendo desvios abruptos que são proporcionados por fraturas. Im relagão aos outros rios da área, é o que apresenta major deposição de aluvião. Em média a arenagem é constituída por cursos d'água pouco profundos e-as aluviões são ricas em material. de granulação grosselra, pouco trabalhado, como é comum ocorrer em zonas áridas sijeitias esporádicamente, ao regime de enxurradas de curta duração.

No alto da Serra da Baixa Verde, em Iriunfo, a pluvios 1 dade média anual é maior do que a regional (1200mm contra $700 \mathrm{~mm}$ ). Também notamos que os solos de alteragão são mals espessos e argi losos e o relêvo mals ondulado. Encontramos predominância de solos caolf́nicos e, em alguns locais, delgadas camadas de laterita fermginosa concrecionar logo acjma do horizonte rochoso.

As encostas da serra são, frequentemente, recobertas por pequenos depósitios de tálus que não foram cartografados no 
presente estágio de trabalhos. A alteração nas zonas mais gnássicas chega a $10 \mathrm{~m}$ de espessura.

Em frente à escarpa Sul da serra encontramos uma série de morrotes alongados paralelamente à mesma que constituem teste munhos de exosão formados por pequenas Iínguas concordantes de sienito, mais resistentes à erosão do que os xistos encaixantes.

\section{GEOLOGIA REGIONAI}

3.1. Tectônica

A área em estudo está encaixada na chamada "zona Transversal" Iimitada pelos falhamentos de Patos ao norte e Pernambuco ao sul, tem sido assim denominada por EBERT (1958) pelo fato das estruturas predominantes apresentarem orjentações EW-NE, em con traste com as estruturas NS dominantes ao sul do lineamento de Per nambuco e NNE no Nordeste Setentrional brasileiro. ALMEIDA (1966) a inclue na faixa dobrada do Cariri, correspondente a um sistema de dobramentos brasilianos com direção dominante NE e inflexões pa ra EW nas proximidades dos grandes Iineamentos acima citcados. A SE da faixa situa-se o bloco Sergipano de Allard (1969).

A zona transversal apresenta, além das falhas transcorrentes de Patos e Pernambuco que a delimitam, falhas transcorrentes, possívelmente, associadas, que cortam a região nos sentidos EW e NE. Estas falhas transcorrentes menores e a disposicão em $S$ das estruturas sugere à primeira vista um sentido dextral aos ras gamentos maiores. Por não terem sido deteminadas estruturas que 
viessem comprovar a deformação de sedimentos paleozóicos da re gião por estat fork de regmagênese, consideramos a meșma como prémdevoniana. Outras falhas, do tipo normal, ocorrem na região inclusive cortando sedimentos paleozóicos e mesozóicos e prová velmente associadas a reativąão Wealdeniana (ALMEIDA, 1966) da Plataforma Brasileira. Falhas de empurrão e normais anteriores ao Devoniano também são citadas na litteratura (SANTOS, 1971), mas não foi dado ao Autor constatar sua existência na área estudada.

\subsection{Estratigraftia}

As sequências rochosas da região pertencem ao sistema que ALMEIDA (1966) denominou de Caririano. São const.jtuidas por metamorfitos de fácies diversas que variam desde a fácies xisto verde até anfibolito, ocorrendo feições granulíticas locais.

A Estratigrafia desta região ainda não foi devidamente eluciada, encontrando-se em fase de elaboracão. Vamos dar um his tórico aproximado da evolução das subdivisões estratigráficas mais divuIgadas para êste Siścema para localização da nossa área de estudos dentro da região.

Em 1910 CRANDAII, separou uma sequência constituida por grauvacas, arcósios, quartzitos, mica xistos e mármores de um embasamento cristajino e a denominou de série Ceará.

Nesta ocasjão, de acôrdo com oś conceitos estratigráficos vigentes considerou-se a série Ceará de baixo grau de netamor fismo e por conseguinte pertencente ao Algonqueano, em contraposi. 
ção ao embasamento de grau de metamorfismo mais elevado, colocado no Arqueano por êste notivo.

Mais tarde EHERT (1962, 1966) aplicando uma conceituação mais elaborada, oriunda da Europa, e baseada em idéias desen volvidas principalmente por STILLF verificou que boa parte do chamado embtisamento migmatítico estaria contido na série ceará de CRANDALI e que o Pré-Cambriano Inferior seria representado só mente em núcleos relativamente pequenos de anticlinais. Estudando com detalhes a região de Borborema EBERT propos a seguinte se quência estratigráfica:

Comę̧ando sempre pelo termo mais jovem, temos:

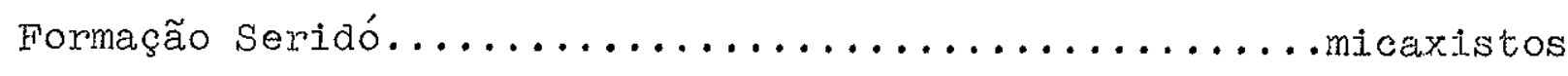
Discordância Suave

Formação Pare]has................... Grauvacas; Arcózios com intercalações de filitos; mármore na parte superior.

Quartzito Equador................... Sequência clástica basal. Mais tarde EBEPI (1966) subdividiu a Formação Parelhas em três Formąões ou seja:

Formação Fłorania.............. retirada da Formação Seridó; sequência alternada de quart zitos e micaxistos

Formação Qujxaba...................ármores e anfibolitos

Formą̧̃o Parelhas................. Sequêncita clásticas finas a médias . 
Posteriormente, EBERT ( ) retornou a um esquema semelhante ao anterior considerando o quartzito Equador como fácies local do polimíctico e clástico Parelhas e o micaxisto seridó como fácies da Formação Florânia.

EM 1967, FERREIRA MEDHTLOS, baseado em mapeamentos geológicos regjonais efetuados por geólogos da SUDENE, considerou. que o quartzito Equador não seria uma formạão basal da série cea rá mas um membro intermediário que indicaria uma fase de regres são com ligeira díscordância separando um complexo superior de ou tro inferior. Êstes complexos que apresentam litologia semelhante podendo somente serem separados por mapeamento detalhado e interpretação das estruturas, foram chamados de seridó e Caicó respectivamente. Mantido o nome da Série Ceará procedeu-se a seguinte subdivisão: 
Formação seridó...........micaxistos

Complexo serj.dó

Formạ̃ão Jurucutu..........Conglomera

dos e grauvacas

com lentes inter

caladas de calcá rio.

Formação Caicó........micaxistos inclu sões de arcózios

e mármores

Formą̧ão S.Vicente.... metaarcozios com Complexo Caicó com inclusões de anfibolitos.

Formą̧̃̃o Lages......... alternancia de micaxistos com metararcozios com lentes quartzít主 cas. 
Em 1968, ALMEIDA et AL. apresentaram uma subdivisão do Pré-Cambriano do Nordeste em base de trabalhos realizados por ou tros autores anteriormente e em 80 determinações geocronológicas das quais no mínimo 50 foram dedicadas ao Caririano. A subdivi são resultante é semelhante à última representada acima, ou seja:

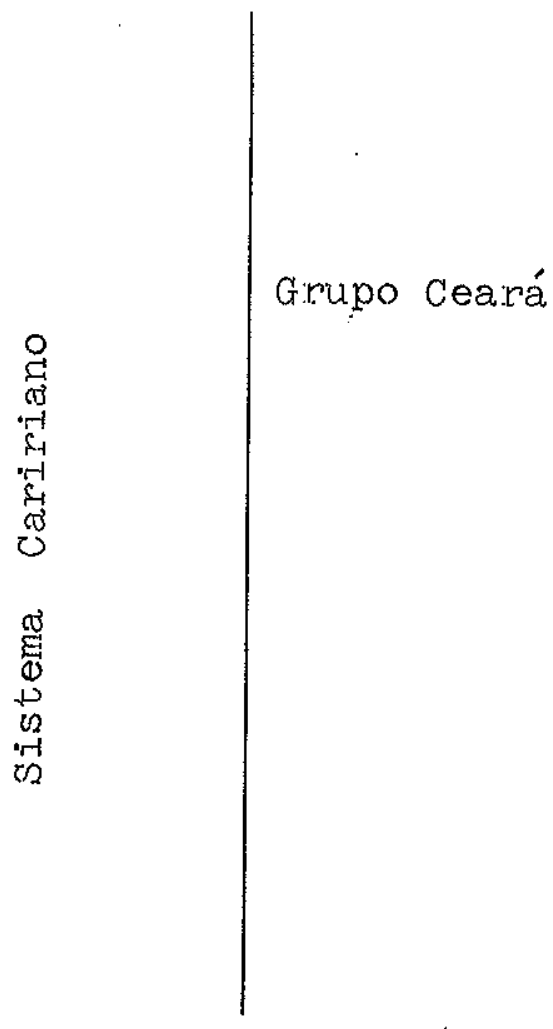

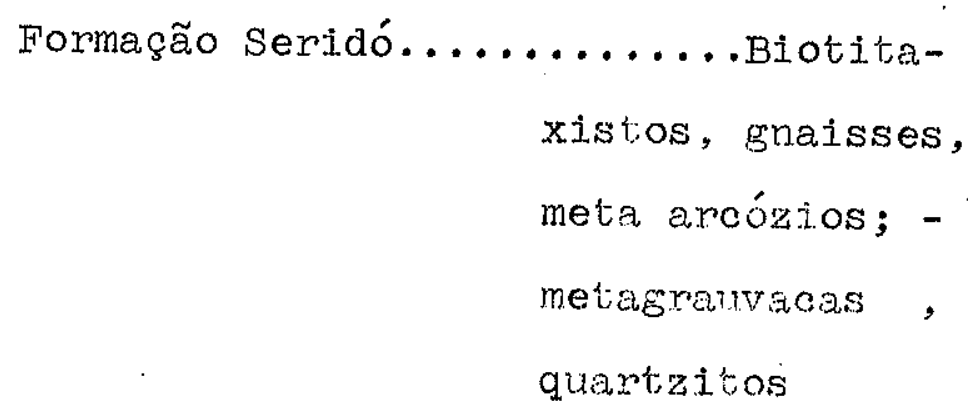

Formação Seridó...........Biotitaxistos, gnaisses, meta arcózios; metagratracas, quartzicos

Formação Equador........QQuartzitos

Formação caicó............ Biotita xis tos, meta arcó zios, metagrauva cas, quartzitos. 
Desta forma, a Formąão Caicó seria constituinte do em basamento, o qual, por sua vez, está recoberto por metassedimentos geossinclinais do Grupo Ceará.

Anfibólios de metagabros intrusivos na Formagão Cajoó apresentam idades de $186083 \mathrm{~m} \cdot \mathrm{a}$. e 1470 . $70 \mathrm{~m} \cdot \mathrm{a}$. como também uma hornblenda de anfibolito e uma biótita de um migmatito da própria formą̧̃o, idades de $1050 \quad 120 \mathrm{~m} . \mathrm{a}$. e $90545 \mathrm{m.a}$. res pectivamente.

Para o Grupo Ceará considerou-se que as idades situadas entre 640 e $530 \mathrm{~m}$.a. corresponderiam ao episódio de metamorfismo principal da orogenia e à formação de granitos e, granodioritos e sienitos tardj. e pos-tectônicos.

Uma jade de $440 \mathrm{~m}$.a. seria referente ao último evento tectônico magmático ào ciclo Caririano.

Em trabalho apresentado en 1968 e publicado em 1970 EBERT propós a seguinte subdivisão baseado inclusive em 30 datações geocronológicas $\mathrm{K}^{40} / \mathrm{Ar}^{40}$ : 


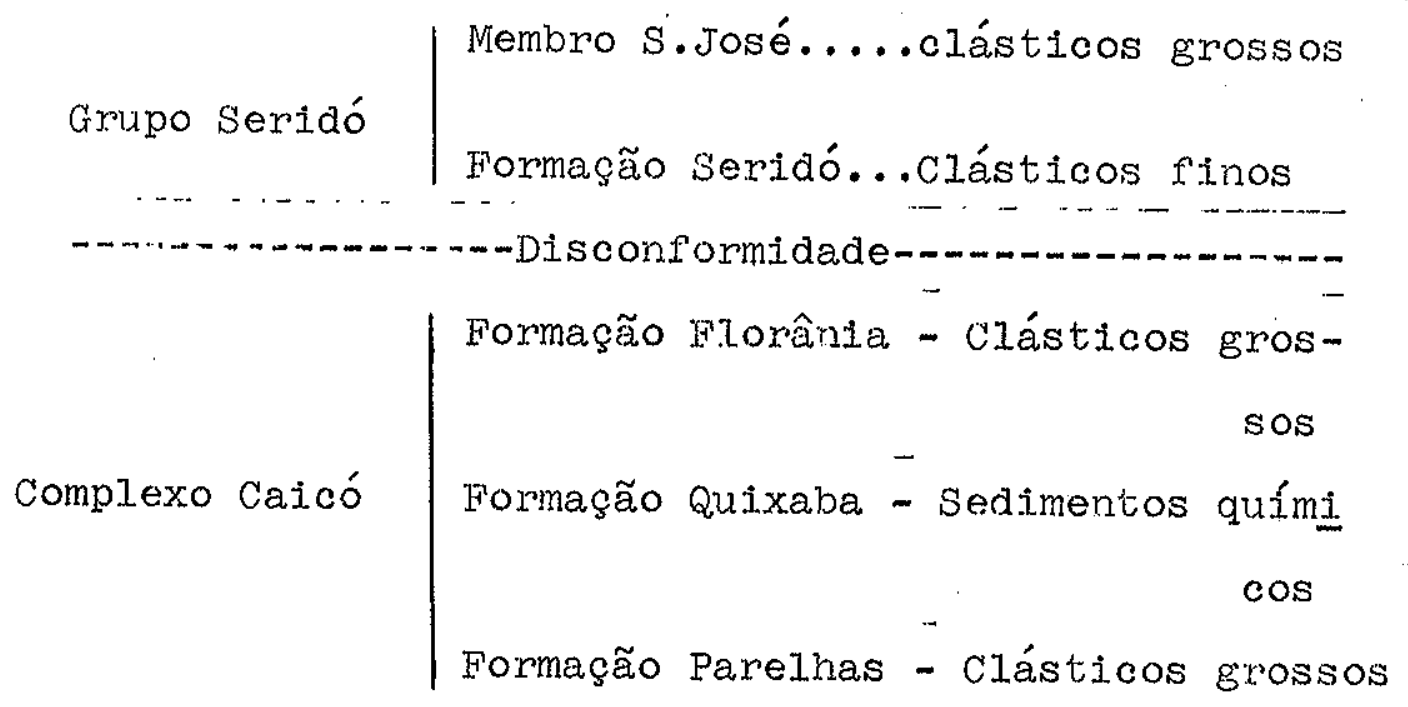

Pré-Cambriano Médio ou mais antigo

Grupo s.Vicente..........migmatitos.

EBERT considera que a princjpal fase de metamorfismo te ria ocorrido no mínimo há $850 \mathrm{~m}$.a. sendo provável que as idades entre 450 e 550 m.a. correspondem a uma fase de plutonismo final. do ciclo orogênico.

Êstes dois valores se enquadram nos episódios tectocené ticos que caracterizarn o ciclo Brastiliano conforme o último traba Iho publicado por AIMEIDA (1971) sôbre a Geocronologilia do Pré-Cam briano da América đo Sul.

Um dos trabalihos mais recentes, específicos sôbre a região é o Projeto Cobre cujo texto foi redigido por BARBOSA (1970). Im base de dados não publicados, êste autor, correlaciona Formações do Craton de São Francisco, do geossinclinal Sergipano e do Sistema Caririano. 
A sequência estratigráfica - tectônica sugerida é a seguinte: (comegando pelo mais antj.go)

Grupo Caraiba - migmatitos com paleosoma anfibolítico Associação de migmatitos biotíticos, meta arcozias, mármores, piroxênio gnaisses, granitos róseos, grano diortios. Intrusivas bástcas e ultrabásicas assocladas.

Grupo Uauá

- biotita gnaisses, biotita xistos, meta grauva cas, muscovita xistos, leptinitos muscovita, gnaisses, quartzitos, itabiritos anfibolitos, mármores, sienitos e cranjtcos tardi tectônicos. Vulcanismo basáltico

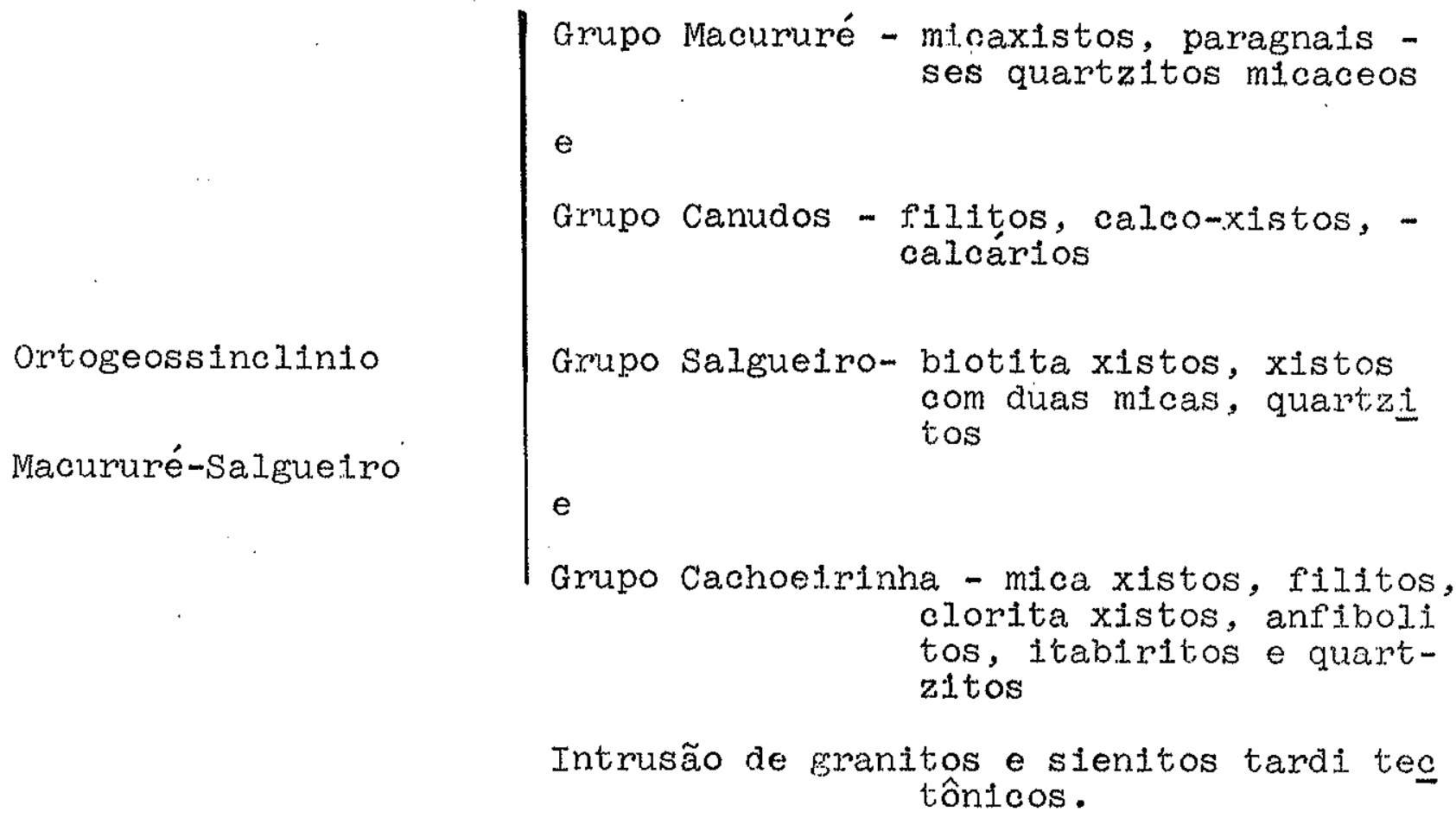

Grupo Cachoeirinha - mica xistos, filitos, clorita xistos, anfiboli tos, itabiritos e quartzitos

Intrusão de granitos e sienitos tardi tec tônicos. 
Regmagênese e serpentinização de Intmusivas ultrabásıcas. Tectônica de cração magmatismo extrusivo toleftico. Regmagênese Patos e Pernambuco e Intrusão de sienitos sub alcalinos.

Segundo o citado autor as relagões estrat1gráficas acima citadas ainda estão à espera de estudos geocronológloos e de considerações finais sendo, por conseguinte, provisórtas. Supõe ainda que os xistos Salgueiro e Cachoefrinha serlam correlatos com a Formaç̃o Pareihas e Seridó de EBERT respectivamente.

Ao estudarmos os mapeamentos de BARBOSA (1970) e EBERT (1970) notamos numa faixa de recobrimento, ao sult da Borborema, em que a Formação Parelhas de EBERI se situa em área considerada como Grupo Uauá por BARBOSA o mesmo acontecendo com a Formąão se ridó relativamente ao Grupo Cachoeirinha. Consequentemente o Grupo Salgueiro ou Grupo Uauá encontram-se deslocados. Lembramos ain da que no mapeamento de nossa área encontramos na região denomina da como Uauá por BARBOSA, xistos de duas micas que o c1tado autor atribue ao Grupo Salgueiro. Por ter sido nosso mapeamento de peque na escala e por não termos em mãos as justiflcativas da subdivisão efetuada resolvemos deixar a questão em aberto adotando no nosso mapeamento a legenda proposta por BARBOSA apenas por ser a de desig nação mais recente. Frisamos ainda que êste foi o levantamento geo lógico regional mais completo do que os publicados anteriormence sôbre a região de interêsse.

No referente às coberturas sedimentares de plataforma de idade paleozóica e mesozólca como a de Araripe e outras bacias 1o- 
cais situadas na zona transversal não as consideramos aqui por fugir aos objetivos dêste trabalho.

Sedimentos recentes como já tjvemos oportunidade de citar são constịtuidos pelos aluviões quaternários dos rios da regitão.

4. GEOLOGTA DO MACISO ALCALINO

\subsection{Rèacôes de contato.}

- maciço da Serra da Bajxa Verde está encaixado em ro chas xistosas; tendo o Grupo Cachoelininha no sen flanco noroeste e os metamorfitos do Grupo Uauá na sua borda restante. A áre a estudada "in 10co", pelo autor, envolveu sòmente o corpo in trusivo e seus contatos na fajxa sul, não tendo sido pesquisadas com major detalhe, por dificuldades de acesso na ocasião, as re lações de contato com o Grupo Cachoeirinha. Notamos entretanto que as observações em fotografias aéreas associadas a algumas evidências de campo revelam um contato por falhamento transcorren te com êste último Grupo.

Na zona de contato do maciço sienitico com o Grupo Uauá, êste, apresenta uma faixa feldspatizada com notável enriqueclmento em microclina. Outrossim, notamos intercalações sieníticas intrusivas ou encalxadas entre as falhas, dentro das metamór ficas, pâralelas em direção à xỉstosidade.

Em alguns locals, nos cortes da rodoviá $P E-18$ e proximidades as relações de contato são confusas à primelra vista, por 
apresentar a intrusiva, uma lineação de máficos concordantes com a direção de gnaissificação da auréola de contato ou seja com djreção IN70W a EW.

Em quase tôda a faixa sul do contato o nicaxisto apre senta xistosidade mergulhando contra o macico e, nas suas proximidades, já nas faixas microclinizadas temos mergulhos sub-verticais notados na foliação, frequentemente, obliterada pela recristalização. Em alguns pontos de observação notamos Inclusões orien tiadas de máficos na zona de contato que mais tarde verfficamos sexem restos de micaxistos alcalinizados, imersos em matriz siení tica.

Na região em que o maciço apresentou composição próxima à rocha granítica não localizamos zonas de feldspatizậão da en caixante mas apenas uma incipiente turmaljnizacão.

Em virtude da área de exposicão do plúton abranger mais de $1.00 \mathrm{~km}^{2}$ conforme podemos verificar no mapa, podemos classificálo como batólito segundo DALY ( ).

\subsection{Iitologia}

4.2.1. Genera.Lidades

No trabalho em pauta, restringimo-nos ao estudo nacro e microscópico preliminar das rochas relacionadas diretamente com a intrusão não tendo sido estudados os mica xistos do Grupo Cachoei rinha ou seridó pelos motivos já expostos acima e nem os migmatitos da área Sudeste do nosso mapa geológico. Lembramos que o contato dos micaxistos do Grupo Cachoeirinha com a Intrusão apresenm 
ta caráter tectônico. No que tange aos migmatitos é provável que não tenham relação direta com a intrusão pois como cita BARBOSA (1970), os micaxistos Uauá encontram-se migmatizados nas áreas de maior deformação.

\subsubsection{Micaxistos}

Os micaxistos analisados são os do Grupo Uauá, segundo já estabelecido. Possuem tintercalações de camadas quartzíticas centimétricas concordantes com a xistosidade e que em certas circunstâncias favorecem boa visualizạãa das estroturas tais como dobras e pequenas falinas. Não efetuamos o estudo minucioso destas camadas constatando sua composição apenas por observação de campo. os xistos apresentam-se migmatizados en certos looais. Na parte Sudeste do mapa geológico notamos que a migmatizagão é mais inten sa, acompanhando zonas de forte deformação observada Inclusive nas rotografjas aéreas e num rápido exame de campo.

A colorąão dos mica xistos é cinza escura e a sua granulação média a fina. No que tange a uma definição da fácies de metamorfismo constatamos a presenca de biotita e muscovita bem cristalizadas funtamente com traços de plagioclásio, não tendo si do possível definir a fácies, o que requer investjogucoes adjcio nats. Dada a sua composiçăo modal (Vide tabela no 1), estas rochas foram classificadas como biotita-muscorita - quartzo xisto. Nas proximjdades de corpos graníticos pequenos, intrusivos nestes xistos, f'oi observada pequena quantidade de turmalina. 


\begin{tabular}{|c|c|c|c|c|c|}
\hline Mineral & Micaxisto & $\begin{array}{l}\text { Rocha hibri } \\
\text { da a borda }\end{array}$ & $\begin{array}{l}\text { Graisse de } \\
\text { transicão }\end{array}$ & Sienito & Granito \\
\hline Quartzo & $55,1 \%$ & $9,8 \%$ & $28,5 \%$ & $5,4 \%$ & $19,4 \%$ \\
\hline Microclina & $\cdots \cdots$ & 60,6 & 62,0 & 68,9 & 51,6 \\
\hline Plagioclásio & $x x$ & 17,4 & 0,8 & 11,5 (AB) & $8,9(A D)$ \\
\hline Hornblenda & $\cdots \cdots$ & $\cdots \cdots$ & 4,0 & $\ldots \ldots$ & $\ldots \ldots$ \\
\hline Hornblenda sódica & $\ldots \ldots$ & 3,0 & $\ldots \ldots$ & 1,1 & $\ldots \ldots$ \\
\hline Augita sódica & $\ldots \ldots$ & 8.3 & $\cdots \cdots$ & 11,5 & 16,3 (ca) \\
\hline Muscovite & 28,0 & 2,0 & $\ldots \ldots$ & $\cdots \cdots$ & $\ldots \ldots$ \\
\hline Biotita. & 13,8 & 0,5 & 4,0 & $\cdots \cdots$ & 1,3 \\
\hline Apactio & $\ldots \ldots$ & 1,0 & $::: \cdots$ & 0,4 & 0,2 \\
\hline Titanita & $\cdots \cdots$ & 1,4 & $\cdots \cdots$ & 0,5 & 0,2 \\
\hline Zireão & $\cdots \cdots$ & $\cdots \cdots$ & 0,2 & 0,1 & 0,4 \\
\hline Opacos & 3,19 & 2,0 & 0,4 & 0,5 & 1,8 \\
\hline Carbonato secundário & $\ldots \ldots$ & $\ldots \ldots$ & 0,1 &.$x x$ & $\ldots \ldots$ \\
\hline
\end{tabular}

Tabela no 1 - Médias Aritméticas das Análises Modas da Rochas Estudadas 


\subsubsection{Gnaisses de transigão}

Formando uma auxéola na borda do corpo intrusivo de com posição sienítica, temos uma zona de microllna gnaisses com bioti ta e hornblenda.

Sua textura é granoblástica orientada apresentando-se em alguns pontos totalmente granular e sem orientagão visível. A hornblenda mos'ra-se asisoctada com a biotita e não foi encontracla muscovita presente nos xistos. A fácies de metamorfismo correspon dente poderia ser definida como anfibolitco. o microclinio apresen ta-se hipidiomorfo com a forna de porfiroblastos sendo pertítico e com frequente geminąão em grade alotita-pericjínto.

Os grãos de microclina apresentam frequentemente fraturamento nas bordas e fissuras preenchidas por carbonatos secindários. Esta aparência de bordas esmigallhadas (textura "Mortar") ca racteriza uma cataclase posterior a sua cristalizaça. Outros minerais como biotita e oligoclásio cambém se apresentam fraturados. Os grãos de quartzo apresentam exilinção ondulante. Esteis gnaisses formam uma fajxa de aproximadamente $800 \mathrm{~m}$ de largura na horizontal apresentando características variáveis conforme nos aproximamos dat intrusão. A algumas dezenas de metros da intrusão encontramos pequenas lentes de máficos, centímetricas e orientadas nas quais, o anfibólio sódico, que também ocorre na f́gnea, aparece assoctado com a bioitita ocorrendo também uma associacão da microclina com o quartzo o que eventualmente pode ser considerado como evidênctas de um processiso metassomátıco lligado á adicão de álcalis. Neste lo 
cal a gnaissificação da matriz clara esta obliterada apresentando a rocha uma textura granular. o plagioclásio desta zona foi definido como albita $\mathrm{An}_{8}$ pelo método Michel. Levy. Tais aspectos aliados à passagem quase total das biotitas para anfibólio e a dimi nuição de quartzo com aumento de microcilna constatada em xenólitos e micaxistos encontrados no sienito sugerem um processo de fe nitização.

\subsubsection{Sienitos}

Quanto à rocha intrusiva na parte oeste do maciço, esta foi classificada como quartzo sienito segundo a classificąão de NIGGII e sienito segundo JOHANNSEN em base de análises modais efe tuadas em quatro amostras coletadas em diferentes locais do macico. Sua textura é fanerítica média dentro do corpo maior e fina nos corpos menores. A porcentagem de quartzo de amostra para amos tra variol de $8.8 \%$ a $1,4 \%$. Ao tentarmos classificar a rocha segun do os critérios adotados por JOHANNSEN notamos certa dificuldade em definí-la como granito alcalino, mas procurando com maior acui dade, notamos que a presença de augita sódica favorece a sua clas sificação como stenito. Segundo NIGGLI a rocha estudada estraria definida como quartzo sienito. Sua composjęão mineralógica modal como a de outras rochas citadas no trabalho em questão se despren de da tabela no 1. O mineral dominante é o feldspato Microclínio caracterizado inclusive pela sua geminação em grade. A augita apresenta alongamento óptico negativo paralelo ao elxo c e amarelo ou amarelo esverdeado perpendicularmente a c. o ângulo de extin ção X⿳⺈ medido foi de 318, em virtude do que consideramos o mineral 
como auglté sódica. Foi definido também o anfibólio azulado nesta área, tanto nas rochas da zona de transição como no sienito, como sendo do tipo sódico. O mesmo apresenta-se em forma de agulhas ou em massas de côr azulada, com o segulnte pleocroismo:

$X$ - verde claro $\quad \mathrm{Y}$ - violeta claro

Z - azul claro

0 ângulo $2 V$ estimado mostrou ser médio.

A principal dificuldade na determinação dêste anfibólio fol a existência de um ângulo zê de $\approx 30$, maior do que o encontra do usualmente em minerais análogos da série Eckermanita/Arfvedsonita. Todavia COUIINHO e VANDOROS (1968) estudando um sienito semethante situado a $100 \mathrm{~km}$ da nossa área, em S.Goncalo no Estado do Paraíba, demonstraram a mesma dificuldade.

Segindo êstes autores, que inclusive realizaram análises químicas dos minerals, o anfibólio sódico que mais próximo está do mineral citado seria a richterita. Baseamo-nos neste trabalho após contato com um dos autores e por serem as proprledades ópticas por nós definidas, pràticamente idênticas às expostas no mesmo. Além disto o maciço parece situado na mesma faixa geossinclinal.

o maciço de S.Gonçalo também apresenta uma Iineação proe minente dos seus máfjcos e uma composição modal semelhante ao da Serra da Balxa Verde conforme podemos constatar na tabela abaixo: 
Maciços

S. Gonçalo

Baixa Verde

Minerais

Quartzo

2,2

0

5,4

Feldspatos

71,4

83,0

80,4

Micr. Plag.

19,4

12,0

1,1

Augitta sódica

1,9

3,1

11,5

Acessórios

$0, x$

$0, x$

resto, incluindo carbonatos secun dários

Embora consideremos a amostragem efetuada em ambos os casos como pouco representativa para o estabelecimento de uma composição modal média dos maciços dado o pequeno número de amos tras envolvido ou seja, cinco amostras para o maciço da serra da Baixa Verde e dias para o de S.Gonçalo, tentaremos comparar as principais tendências na variação de composição entre os mesmos. o teor de richterita nas nossas amostras é inferior ao das rochas de S.Gonçalo ocorrendo o inverso com o piroxênio. A maior porcentagem de richterita por nós calculada para uma das amostras foi de $3 \%$

Quanto a efeitos de cataclase, notamos que a maioria dos cristais de microclina apresenta os bordos esmigalhados estando alguns, com fissuras preenehjdas por carbonatos secundários. Ocor rem ainda cristais de piroxênio quebrados e os grãos de quartzo existentes apresentam extinção ondulanìe. 
4.2.5. Granitos

A parte leste da intrusão pelo que pudemos concluir atra vés do exame de campo e posterior constatação das análises modais de duas amostras coletadas, apresenta composição granítica. Segundo os critérios de JOHANNSEN e NIGGLI situa-se entre os granitos alcalinos. É uma rocha de textura fanerítica fina a média com fe.nocristais de 1 a $2 \mathrm{~mm}$ de microclinio, levemente orlentados com evidênejas de esmigalhamento nas bordas. o plagioclásio eviaenciou ser albita $\mathrm{AnO}_{8}$ apresentando rrequentemente geminações Carjsbad e lei da albita combinadas tendo sido notado um zoneamento de cristajs de origem Ígnea. O quartzo apresenta com frequência, extin gão ondulante. o piroxênio mostrou ser uma augita com ângulo de extinção próximo a $45 \%$. Não encontramos anfibólio como no sienito mas, biotita.

4.2.6. Discussão

o batólito apresenta uma composição granítica à leste e sienítica à oeste. A delimitacão entre estas duas composições sómente poderá ser precisada com exatidão após amostragem detalnada. Por enquanto lançamos um contato imaginário baseados somente na a mostragem preliminar.

A existência de zonas de microclina gnajsses na borda sul do corpo sienítico sugere a existência de uma auréola de contato provàvelmente do tipo fenítico. Na falta de análises químicas consideramos que "zona de transição" seria um têrmo adequado a esta faixa. 
Consideramos, pelas relações tênues de contato semelhan ca de composição e pela disposição geológica das diferentes litologias que esta diferença de composição está ligado a um processo de diferenciação durante a formação do batólito.

\subsection{Estruturas}

\subsubsection{Generalidades}

Podemos notar fàcilmente na fotografia aérea, inúmeras das estruturas geológicas da área em questão. Tal observação é extremamente facilitada pela pequena espessura de solo e, ora rá la, ora densa mas esparsa cobertura vegetal. O batólito sobressaese em fotografia pela sua tonalidade mais clara, pela saliência no relêvo e distribuição mais entrecruzada de lineações e pela existência de matações.

No mapa geológico lançamos sòmente as lineações mais evidentes não envolvendo a topografia por estar representada por curvas de nível.

\subsubsection{Xistosidade e dobramentos}

A xistosidade local apresenta em média valores situados entre N70\&W e N7OE com mergulhos dominantes para norte, estas são também as direções genéricas dos eixos de dobramentos medidos nos micaxistos. No caso são os planos de xistosidade que estão corrugados e dobrados. Êstes planos de xistosidade são proporcionados especialmente pela orientação das micas. 
Os dobramentos localizados na estrada entre Iraguaçu e Flores apresentavam-se assimétricos com vergência para sul sendo do tipo contínuo. Nas proximidades das intrusões menores de sienj to a xistosidade contorna êstes corpos tendendo a cair para fora nas extremidades leste e oeste dos mesmos. De uma forma geral a xistosidade cai para norte com ângulos cujo valor oscila por volta de 409 tornando-se maior conforme nos aproximamos do corpo in trusivo.

Os gnaisses de contato que também formam auréolas ao re dor dos corpos menores de intrusão, apresentam atitudes similares às dos xistos apresentando no entanto, junto à intrusão maior mer gulhos sub verticais.

A passagem de gnaisses para xistos é de certa forma interminante e gradual, e nas proximidades do corpo de intmusão ma ior a alternância de línguas ou faixas sieníticas que se intercalam nos micaxistos ou nos gnaisses ocasiona dificuldades na distin cão entre os corpos. Em algumas zonas nota-se uma lineação no gnais se mas incipiente por demals para permitir medidas de mergulho em três dimensões.

\subsubsection{Estruturas do plúton}

As estruturas mais marcantes no macico intrusivo são qua tro a saber:

lineacão proporcionada pelos máficos;

zonas de cataclasitos incluindo milonitos e estrias, evidenciando L em alguns pontos o predomínio de movimentos horizontajem $\mathrm{G}_{0}$

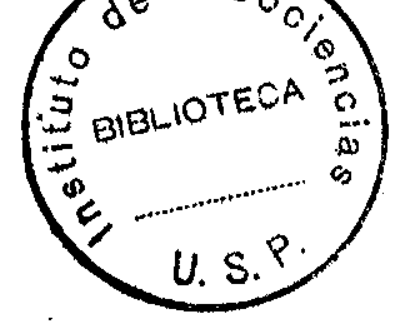


corpos sieníticos com caráter hipoabissal concordantes com a xistosidade e que seriam prolongados do corpo maior;

xenólitos de micaxistos digeridos parcialmente ou alcalinizados e diaclasamento.

A Iineação dos máficos apresenta uma direção doninante N70W que provàvelmente seria perpendicular à direção dos esforços de compressão vigentes durante a intrusão. Tal aspecto chega a proporcionar confusão com a faliação das encaixantes em alguns Io cais.

Os corpos sieníticos situados em frente à escarpa da Serra apresentam-se como Iínguas concordantes com a xistosidade provàvelmente introduzidos pelos planos de roliação proporcionados pela mesma. A granulação dêstes corpos menores é mals finz que a do maciço maior não tendo se notado alguma lineação.

Tanto dentro dos corpo: menores como nas bordas do maci co maior encontramos xenólitos de micaxisto, alguns digeridos par cialmente ou alcalinizados. Nos corpos pequenos os xenólitos apre sentam orientação caótica enquanto que nas bordas do corpo maior encon xantes e sugerjndo digestão parcial das paredes da encaixante.

No que tange aos sistemas de juntas exjstentes não efetuamos levantamento estatístico que nos permitisse a.lguma conclum são. Notamos a existência de juntas associadas à falhamentos e provàvel resfriamento além de um diaclaramento sub-horizontal cuja frequência diminue com á profundidade ou seja de alívio de ten sões (sheeting). 
4.3.4. Falhas

As estruturas planares mais conspícuas inclusive em foto indices de escala 1:80000 são as falhas transcorrentes com dI reção N15E e N50E verticais, que cortam a intrusiva. As zonas de cataclase e milonitização possuen espessuras da ordem de $500 \mathrm{~m}$ e comprimento maior que $20 \mathrm{~km}$ com estriamentos horizontais e sub ho rizontais.

No tocante ao sentido relativo do movimento, o mesmo pa rece ter sido sinistral para a falha que passa próximo a sta.Cruz. Para concluirmos tal novimento baseamo-ros no mapa 1:500000 do Projet;o Cobre ou seja nos deslocamentos associados aos grandes fa Ihamentos de Patos e Pernambuco. As estruturas do bloco situado entre estas duas grandes falhas apresentam-se deformadas de forma sigmoida]. sugerindo rotąão anti-horária do bloco em contrapartida a falhamentos destrais. Tal movimento ocasiona fraturas de tra gão com direção NE e cizalhamentos sinistrais NE e EW como ocorre ria no nosso batóljto. Mas consideramos nossas afirmações ainda como provisórias até que um trabalho específico de maior detalhe sôbre. os rasgamentos citados actma venha lançar mais luz sôbre o problema.

Resta lembrar que a falha Pernambuco foi mapeada como sinistral pelo projeto cobre.

Quanto ao rejeito total dos movimentos não os podemos precisar por falta de dados desponívejs para tal. 
5. DEFTNICAO DO CARÁTER INSRUS IVO E CIASSIFICACAO TECTONICA DO MACICO

\subsection{Caráter Intrusivo}

São as seguintes as características do maciço da Serra

da Baixa Verde que o definiriam como corpo intrusivo:

a) A delimitação relativamente clara do maciço que deformou as es truturas regionais da forma evidenciada no contôrno dos corpos menores associados.

b) A existência de uma auréola de contato feldspatizada passando as encaixantes xistosas a microclina gnaisses com anfibólio sódico, êste último mineral, interdigitado com a biotita é de o corrência constante no maciço intrusivo.

c) A granulação relativamente mais fina dos corpos menores motiva da provàvelmente pelo esfriamento mais rápido durante a consoIidação.

d) A existência de xenólitos com orientação diversa à das encaixan tes.

e) A constatą̧ão da existência de cristais zonados de feldspato.

\subsection{Ciassificacão tectônica}

Resolvemos classificar o batólito em questão como tarditectônico pelos seguintes aspectos:

a) Concordâncìa apenas parclal do corpo com as estruturas das encaixantes segundo podemos observar no mapa.

b) Iineação dos máficos (augita e anfibólio) paralela às estruturas 
regionais indicando cristalização durante a ação de esforços de caráter tectoorogenético.

c) O maciço é circunscrito (vide RAGUIN, 1957, p. 26).

d) A composição mineralógica com domínio de microclina e albita. anos situada entre $\mathrm{Ab} 95 \mathrm{AO}_{5}$ e $\mathrm{Ab} 85 \mathrm{An}_{15}$ própria de maciços tar dicinemáticos (MARMO, 1971, pag. 1941).

e) A localização de macţos semelhantes ocorrentes no Caririano, em faixas de idades situadas no fitm do tectonismo do ciclo Brasilia no (BARBOSA, 1970; VANDOROS, 1968).

\section{CONS IDERACOES FINAIS E CONCLUSOES}

\subsection{Sequência de eventos}

Os dados geocronológicos referentes à intrusiva de S.Gonçalo (COUTINHO e VANDOROS, 1968) forneceram uma idade de $610 \mathrm{~m} . a .$. Tal idade segundo constatamos em ALMEIDA (1971) corresponde à fase tecto-plutônica do episódio tardio do ciclo Brasiliano situado entre $62020 \mathrm{~m} \cdot \mathrm{a}$.

No que se, refere aos falhamentos que cortam a nossa intru siva os mesmos são provàvelmente correlatos com os de Patos e Per nambuco que, por sua vez, são recobertos por sedimentos Devonianos (vide Fôlha Geológica de Arco Verde segundo E. dos Santos, 1971). Por conseguinte achamos razoável colocá-los entre o pré-Cambriano Superior e o Devoniano, ou seja, no Pré-Devoniano Paleozóico.

Enfim, com base nos dados obtidos, propomos a seguinte se quência para os principais eventos tectônicos que se refletiram na área: 
1- Sedimentagão ortogeossinclinal seguida de metamorfismo com idade de aproximadamente $900 \mathrm{~m} \cdot \mathrm{a}$. (seg. EBERT, 1971).

2- Dobramento das mécamórficas pré-existentes e intrusão tardia de granitoides e sienitos no episódio final do ciclo Brasiliano.

3- Durante o Paleoróico inferior deram-se os falhamentos de Patos e Pernambuco, correspondendo à uma fase de regmagênese em condições plataformais. Estes falhamentos foram acompanhados de PaInas secundárias de direção média NNE das quais algumas cortaram inclusive o batólito da Serra da Baixa Verde conforme po dernos observar no mapa anexo.

4- Postexiormente, em caráter regional e segundo a literatura, du rante a reativação Mesozóice da Plataforma Brasileira, falhamen tos normais afetaram a regjä́o. No caso, não conseguimoṣ confi $\underline{r}$ mar a sua presença na área em estudo.

5- Quanto às superfíciest de erosão denominadas como Pós-Gondwana e Soledade por KING e MEUNIER respectivamente, constatamos a sua existência na área ocorrendo ambas nos sienitos e indicando no mínimo duas oscilações epirogenéticas da Plataforma com reflêxo no relêvo.

6-No tocante à uma definição final sôbre a estratigrafia, notamos ser a subdivisão proposta por BARBOSA, a mais completa embora não totalmente esclarecida em seus detalhes e carente de dados geocronológicos prometidos para publicação futura pelo citado autor.

7. Por outro lado, em base de estudos estritamente bibliográficos 
e com relação à pesquisa atual supomos que será bem provável uma correlação estreita com os afloramentos de sienitos semelhantes que ocorrem em áreas tais como o de S.Gonçalo no Pará́ba, e os de Umã, Pajeú e Serra do Padre. Para confirmar tal idéia seriam necessários estudos complementares em grande escala.

8- Datações geocronológicas baseadas no método K/Ar estão em andamento no laboratório de Geocronologia da Universidade de são Pau.lo e poderão ser objeto de futuras comunicações complementares. 


\section{BIBLIOGRAFIA}

\author{
ALIJARD, $G \cdot 0$. \\ ALMEIDA, F.F.M.
}

ALMEIDA ET AI.

BARBOSA, O. ET AL

BEURIEN, K.

EBERT, H.
TERREIRA, E.O.
- The Propriá Geosyncline - XIII C.B.G. pag. 47 a 59 - 1959 .

- Diferenciação tectônica da Plataforma Brasileira - XXIII C.B.G. - pag. 29 a $46-1969$.

- Geochronological Division of the PréCambrian of South America - Rev.Bras. Geoc. - vol. 1, no 1, pag. 13 a 12 1971.

- Radiometric age determinations from Northern Brazil - Bot.Soc.Bras.Geol. 17 pag. 3 a 14, fig. 3 - 1968 .

- Geologia Econômica da Região do Médto São Francisco - Bol. no ,DFPMDNPM - 1970.

-

- Geologie von Brasilien - Gebr.Borntrabger Verlag - Berlin - 1970.

- A subdtrisão estratigráfica e tectônica do Pré-Cambriano no Rio Grande do Norte e Paraíba - Eng.Min e Met. no 43, pag. 37 a 38 - 3 fig. - 1966.

- Obșervacões sôbre a subdivisão estratigráfica e a idade do-Pré-Cambriano do Nordestce Brasileiro - Eng.Min. Met., n8 46 - pag. 111 a 1.13, 2 fig. - 1967.

- Geologia do Alto Seridó, nota explicati va a fôlha geologioa de Currais Novos $=$ 1:250 000. SUDENE (Recife) - Série Geom logia Regional - 1.969.

- The Pre-cambrian geology of the "Borborema" Belt - Bd. 59, Heft. 3 - pag.1292 a $1326-1970$.

- Carta Geotectônica do Brasil. - Avulso DGM-DFPM - 1971. 
KEGEL, $W$.

MARMO, $V$.

MORAES, I.J. e

BARROS, F.C.

RAGUIN, E.

SANTOS, T.J. dOS

Vaneluos.
- A estrutura geológica do Nordeste do Brasil - Bol. DGM, 227; 47 pp., 3 fig. 1965.

- Granite Petrology....Elsevier Publ. Co. Ist edition - NY. - 1971.

- Reconhecimento Fotogeológico da região Nordeste do Brasil, Fôlhas Patos e Triunfo - DFPM - 2960.

- Géologie du Granite - Masson et Cle Paris - 1946.

- As Feições Estruturais da Fôlha Arco Verde, Pernambuco.....Min. \& Me'v vol. IIII, ne 313, pag. 35 a 40 - 1971. 


\section{AGRADECIMENTIOS}

o presente trabalho foi realizado sob a orientação do Prof. Dr. Adolpho José Melfi a quem são dedjcados os primeiros agradectmentos do autor. Ao Prof. Dr. Yociteru Hasui agradecemos pelas inúmeras sugestões e elucidação das dúvidas que surgiram por ocasião da elaboração dos dados.

Agradecemos aos Professores Dr. José Moacyr Vianna Cou tinho e Dr. Vicente Girardi e demais colegas do Departamento de Mineralogia e Petrologia pelia ajuda prestada ao autor no exame de lâminas das rochas provenientes da área em estudo.

o autor agradece ainda a todos aquêles que direta ou Indiretamente o ajudaram na confeção do presente artigo.

Este trabalho foi executado, no que tange à coleta de dados fotogeológ:icos e de campo durante a ocasião em que o autor estava a serviços da VASP AIROFOTOGRAMETRTA S/A. A esta emprêsa também ficam aqui os agradeciunentos do autor. 


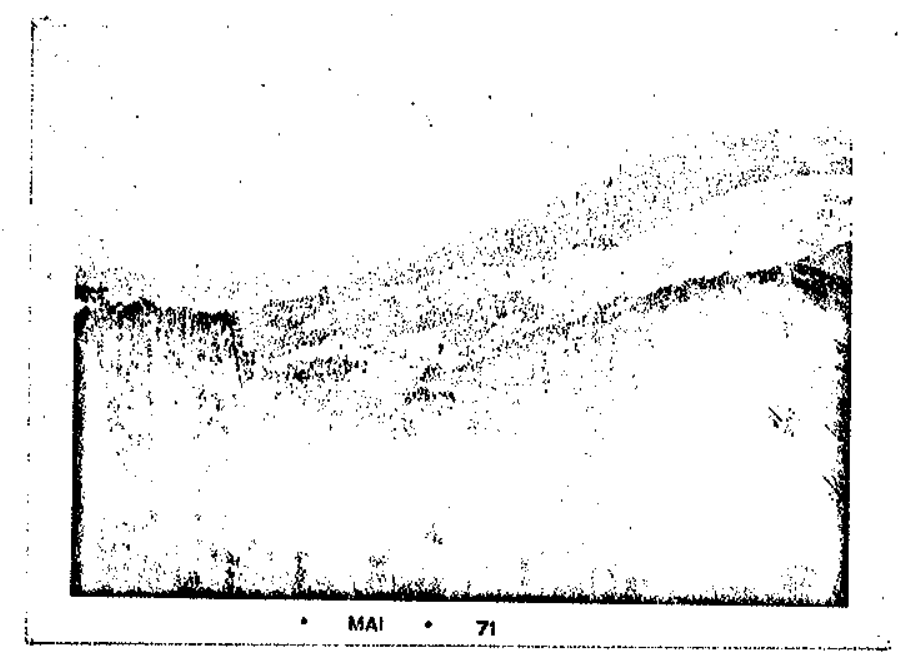

Foto n. I - Vista do flan co sul da Serra da Baixa Verde, 0 tôpo constitue a superfície arrasada pósGondwana e o patamar infe rior, a superfície soledâ de.

Foto n. 2 - Vista dos morrotes sieníticos pa ralelas às estruturas nas planície de micaxisto:- Ao fundo descor tinam-se maciços migmä titicos.
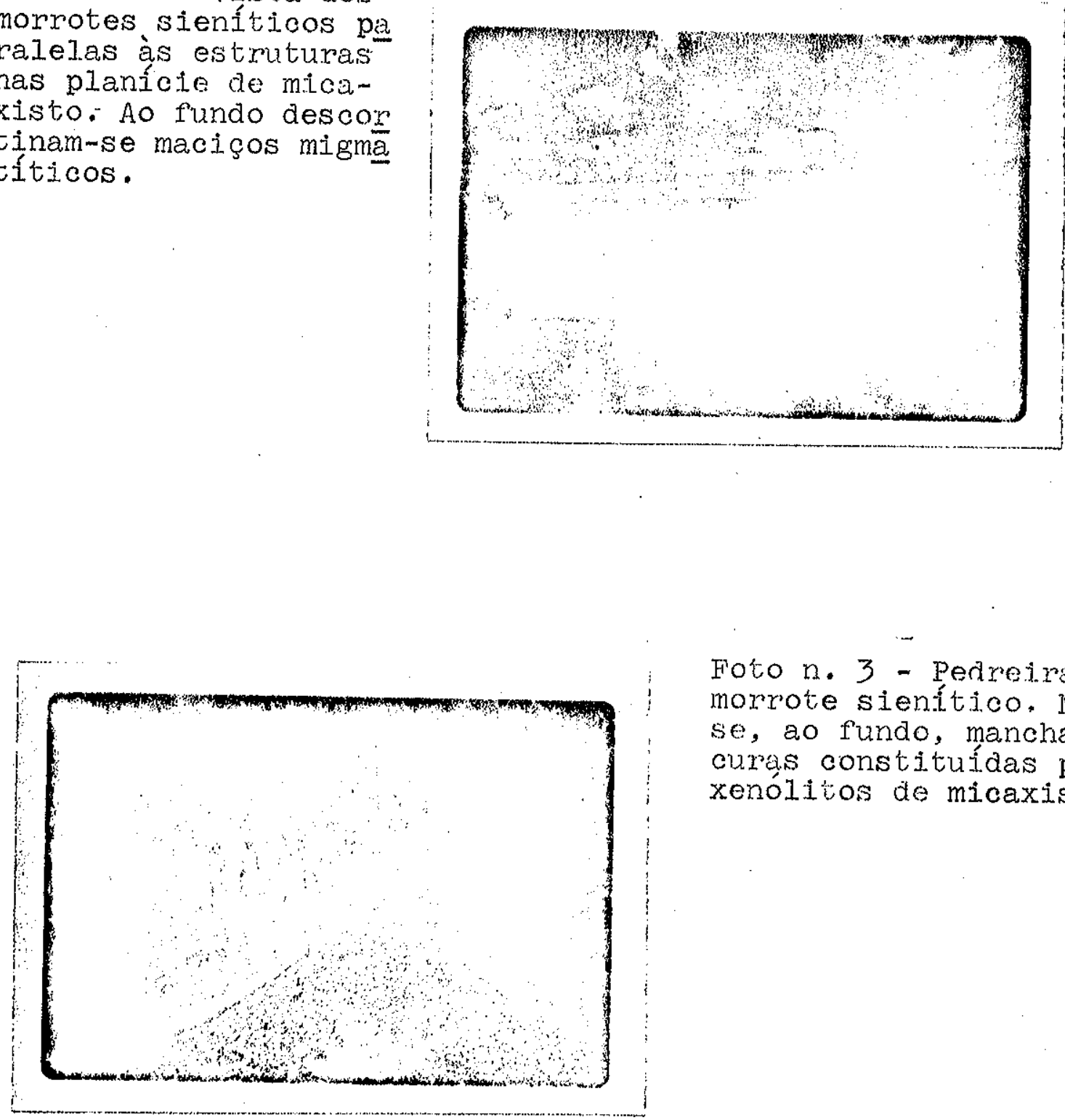

Foto n. 3 - Pedreira em morrote sienítico. Notese, ao fundo, manchas es curas constituídas pelos xenólitos de micaxisto. 


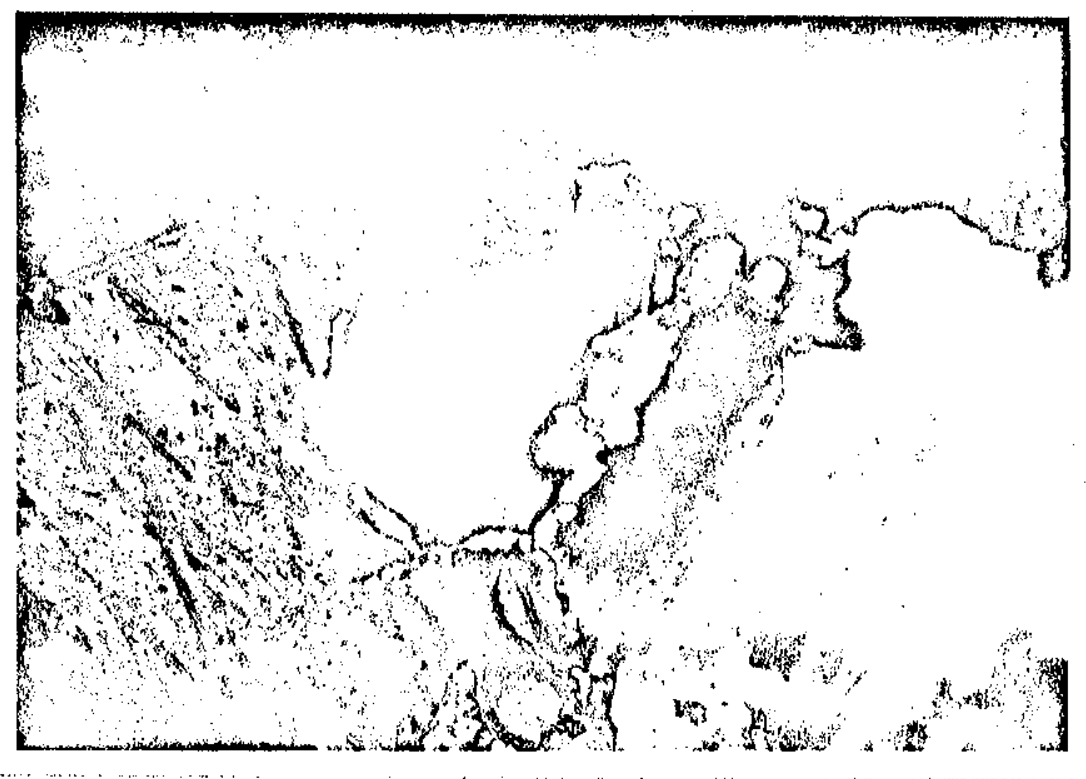

Microfoto nr. 1. Textura "mortar" no sionito. Notamos o cristal de feldspato com as bordas esmigalhadas como cambém fissuras preenchidas por carbonatos secundários nos cristais vizinhos. Nicois t Aumento: $25 \mathrm{x}$.

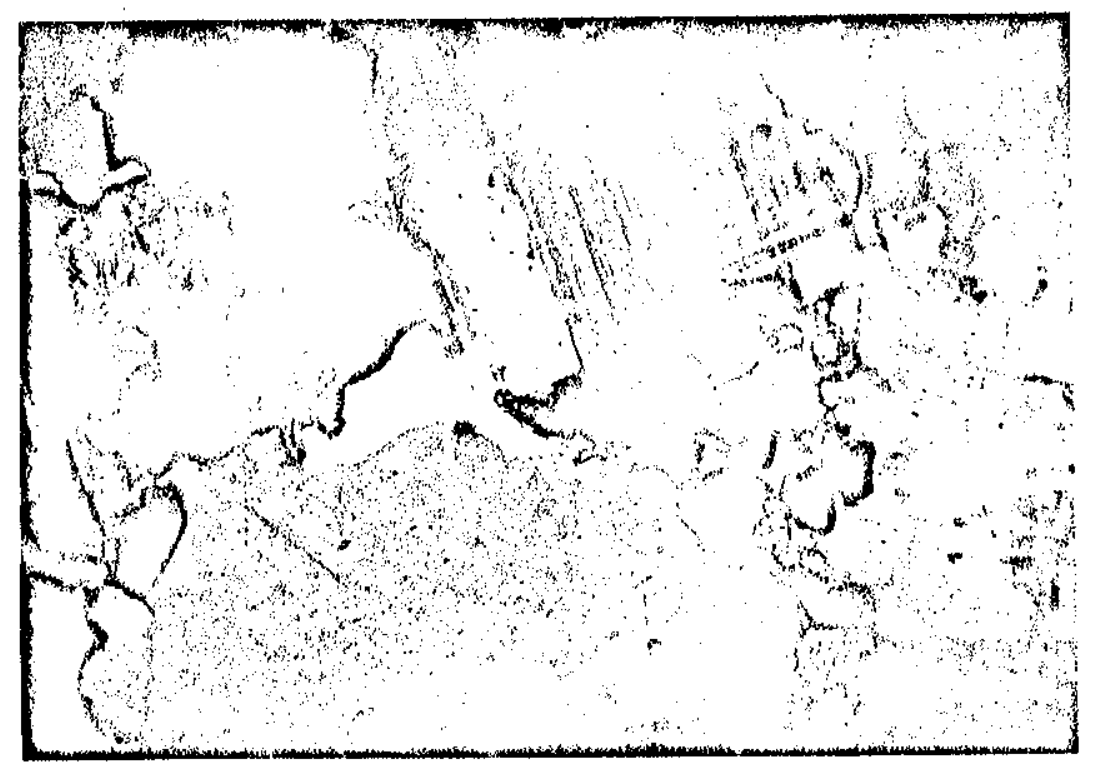

Microfoto nr. 2. Gemjnag̣ão em grade do microclf́nio. Os ćristais escuros são opacos. Sieni to. Nicois f . Aumento $25 x$. 


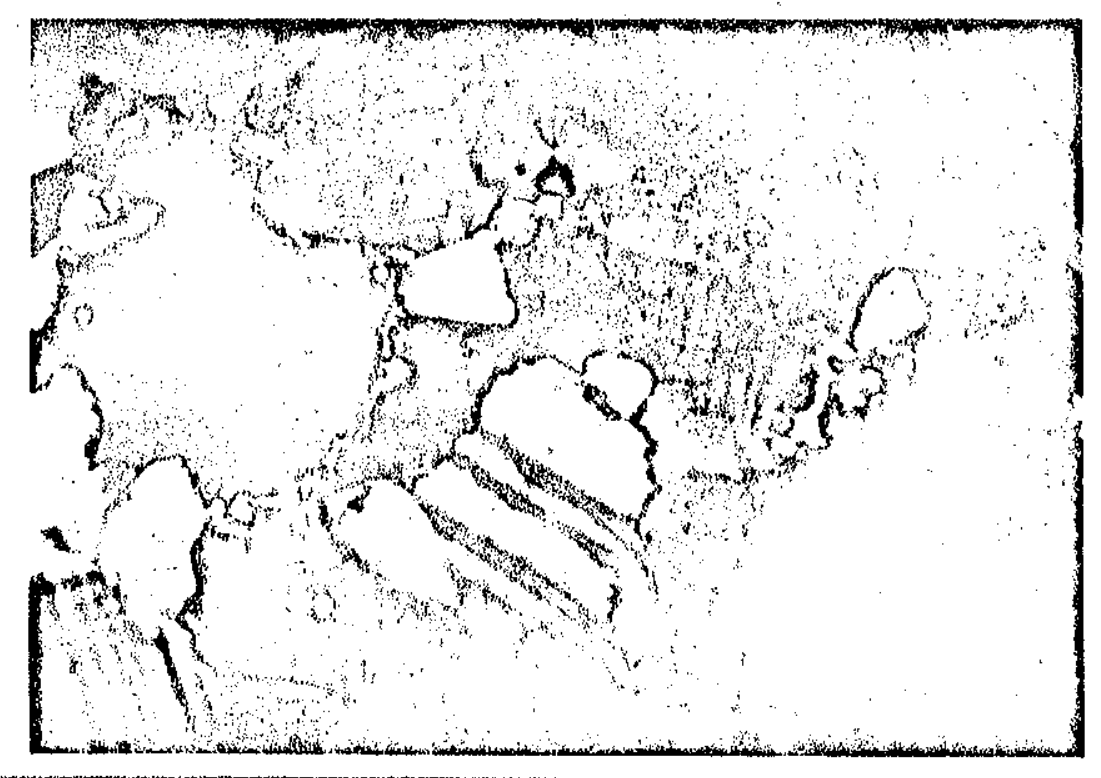

Microfoto nr. 3. Textura "mortar" no sienito. Nicois 4 . Aumento: 25.

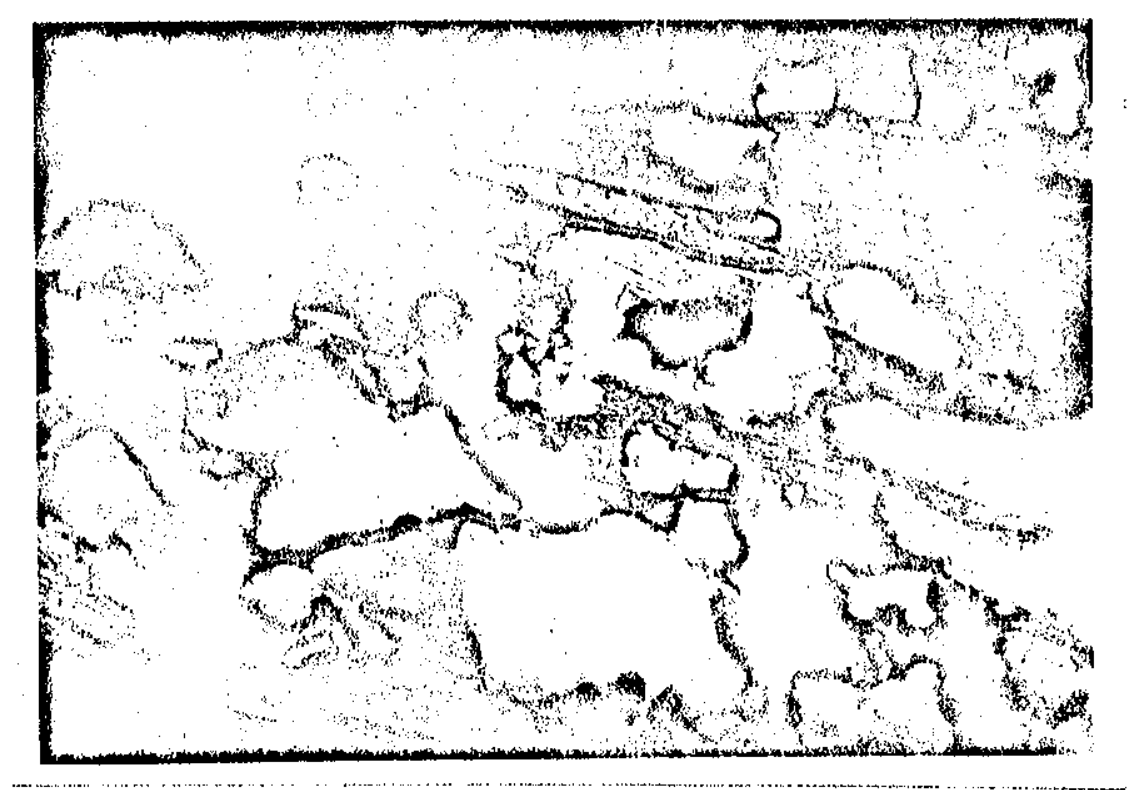

Microfoto nr. 4. Aspec'co do mica xisto. Os cristajs alongados em seccão, mais escuros são bioti tas intercrescidas com muscovita mais clara. Nicols cruzados - Aumento: $25 \mathrm{x}$. 


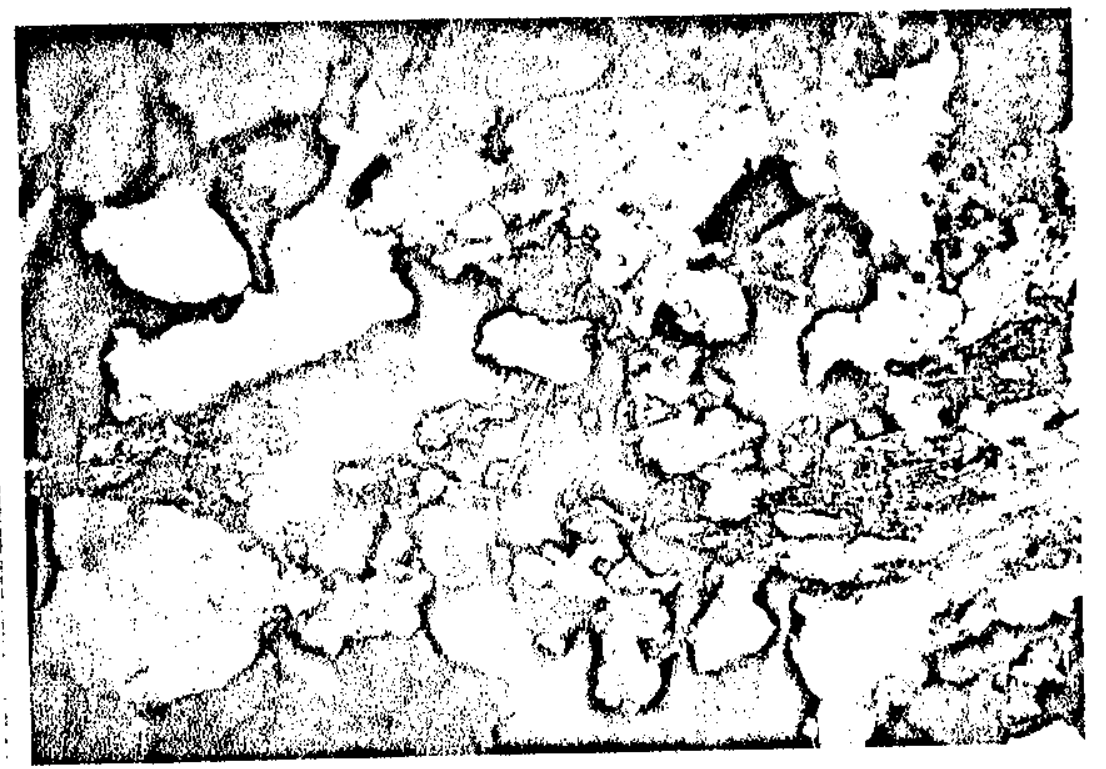

Microfoto nr. 5. - Aspecto do mica xisto Note-se no centro o cristal de albita fra turado. Nicois cruzados. Aumento: $25 \mathrm{x}$.

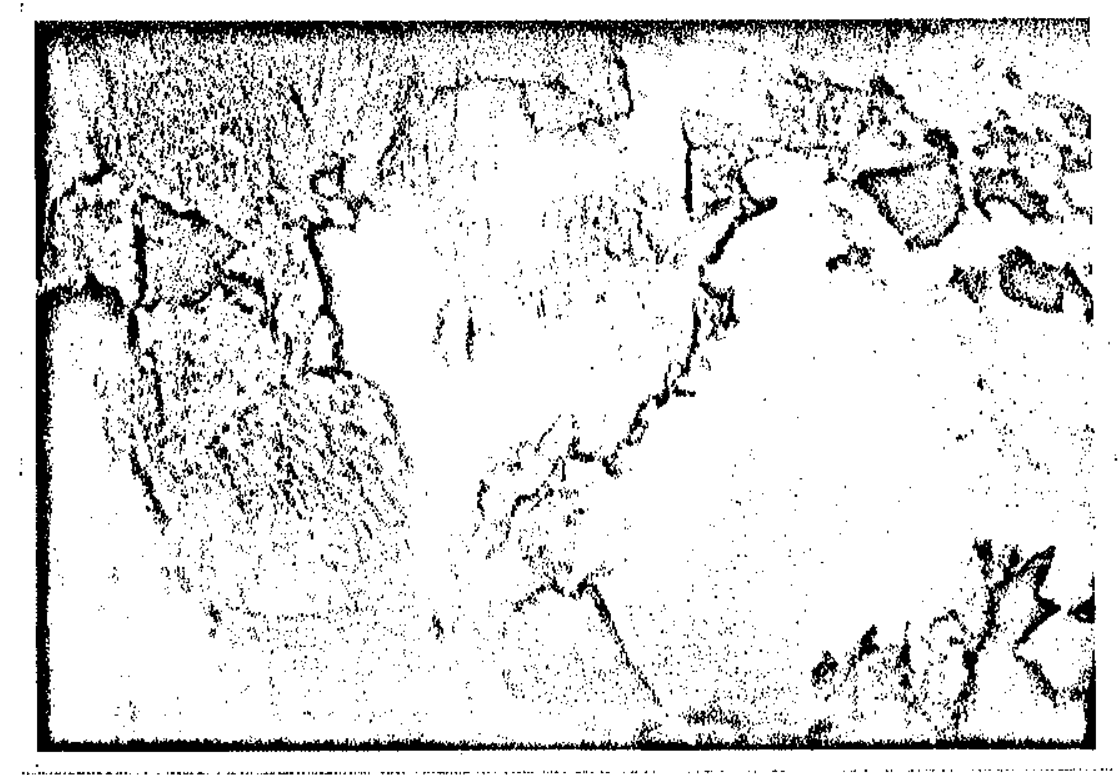

Microfoto nr. 6. Aspecto da rocha da zona de transicão. Notamos aglomeração de cris tais de anfibólio sódico mais escuros. Nicois of . Aumento: $25 \cdot \mathrm{x}$. 


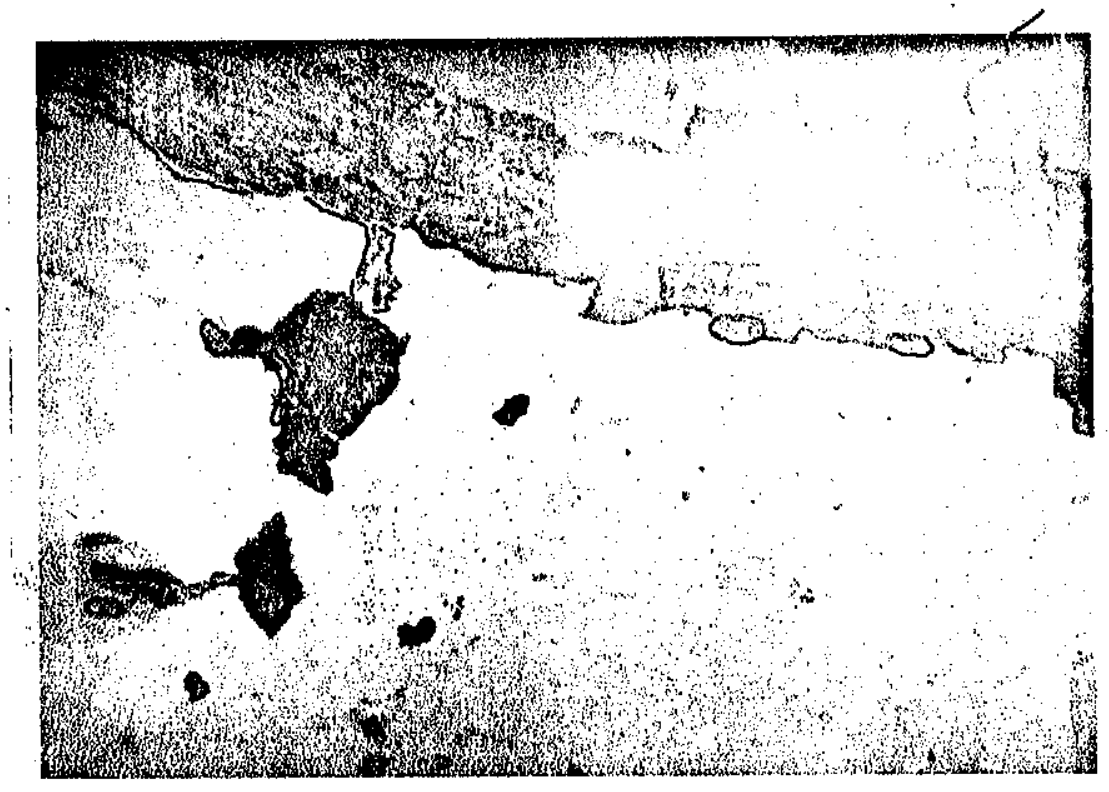

Microfoto nr. 7 - Cristal de augjta sódica com borda de reação de anfibólio sódico. Por ser azul claro êste último é dificilmen. te notado no fotografia tendo sido assinala dos a tinta os trechos mais evidentes. Sie=nito. Nicois //s. Aumento: $25 \mathrm{x}$. 


\section{MAPA GEOLÓGICO DA SERRA DA BAIXA VERDE - PE.}

FÖLHA BASE: SUDENE; SERRA TALHADA - PERNAMBUCO

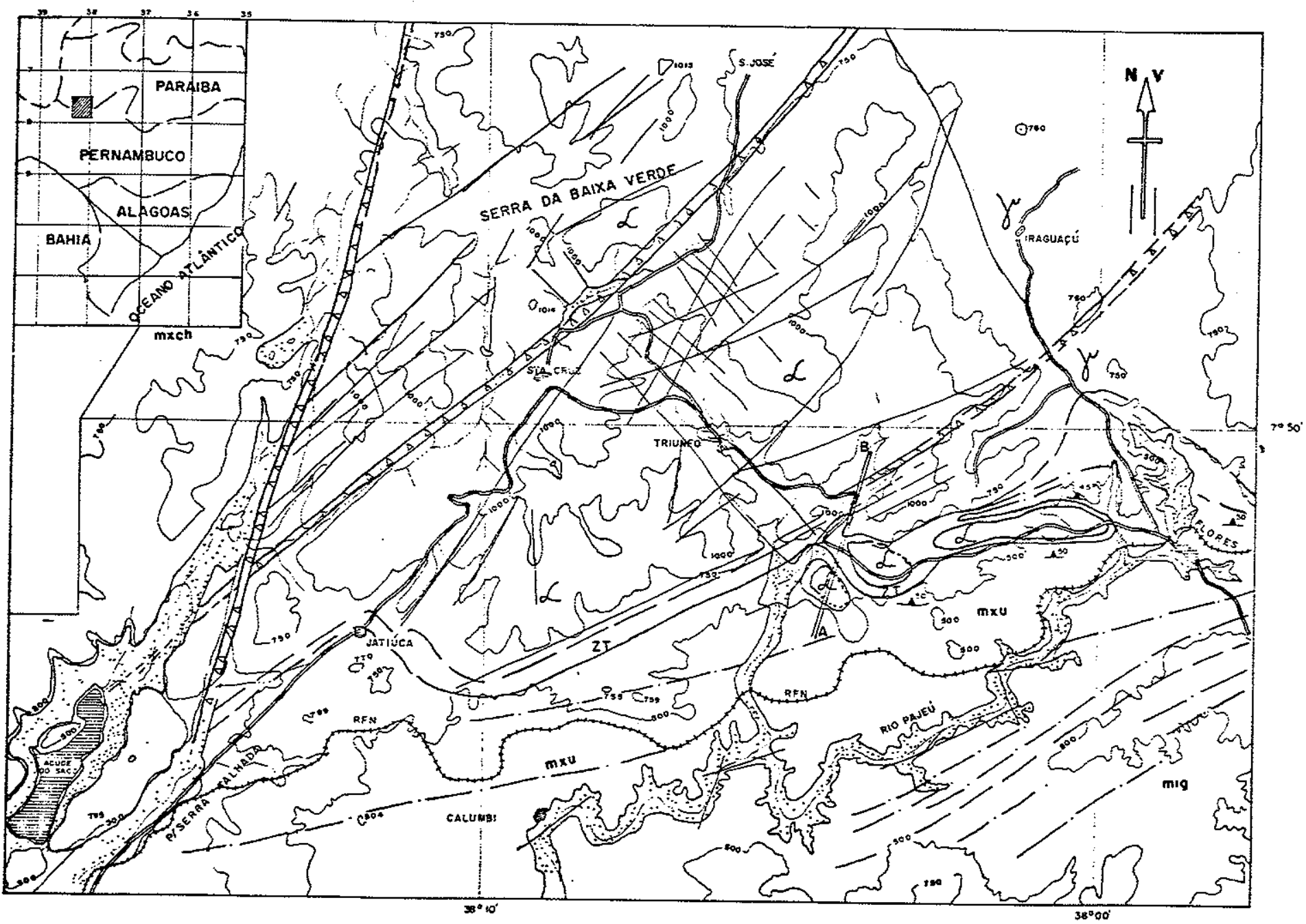

\section{LEGENDA}

QUATERNÁRIO

SEDIMENTOS ALUVIONARES

PRÉ - DEVONIANO

Go. MLONITOS E CATACLASITOS EM GERAL

PRÉ-CAMBRIANO

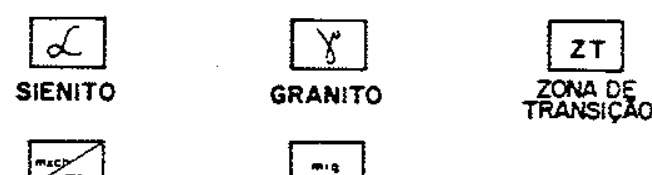

MICAXISTOS (mx) DOS GRUPOS UAUA E CACHOEIRINHA E MIGMATITOS (mig)

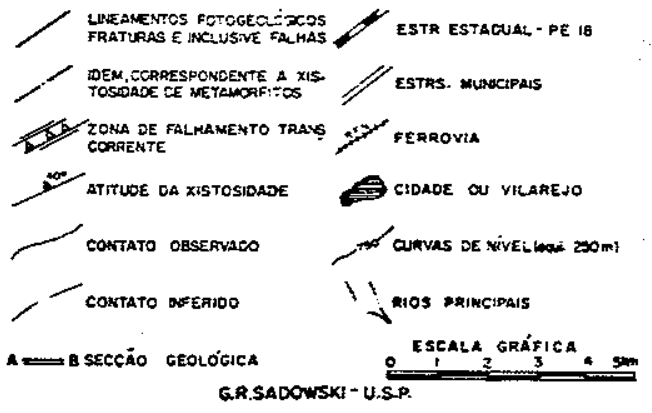




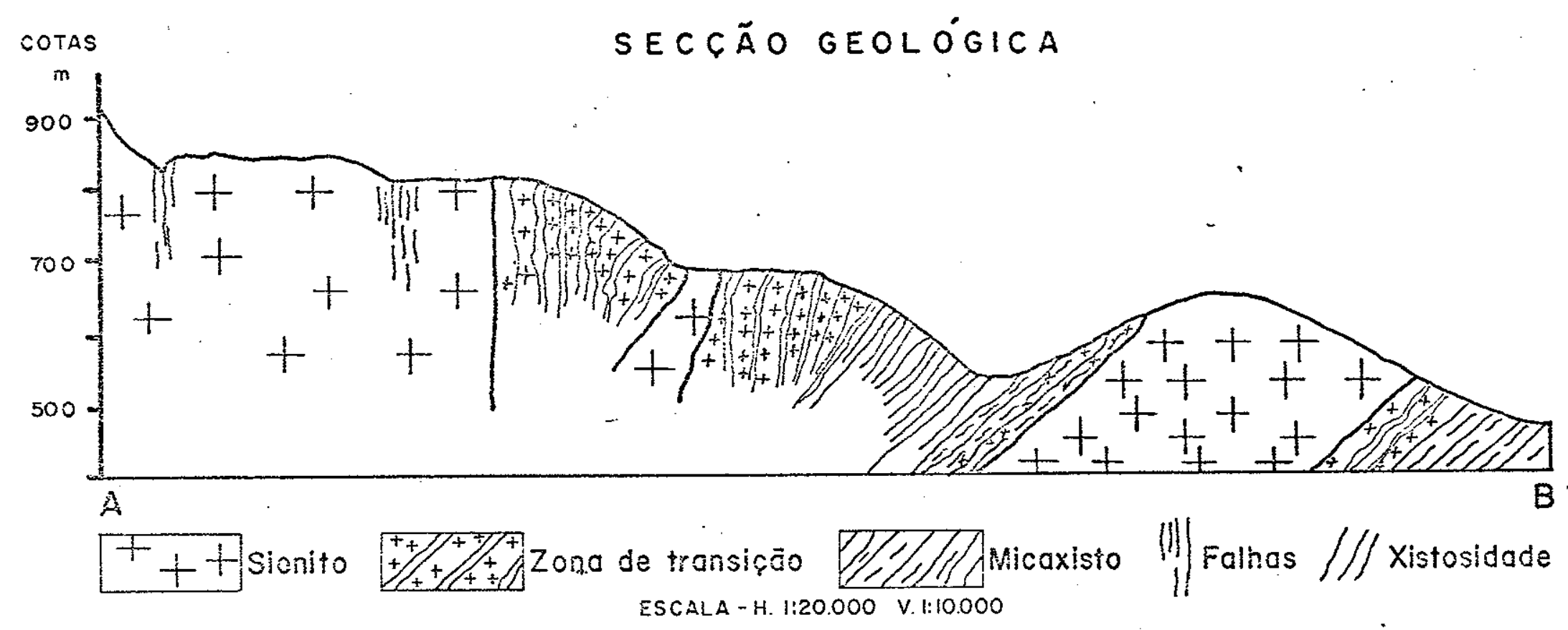




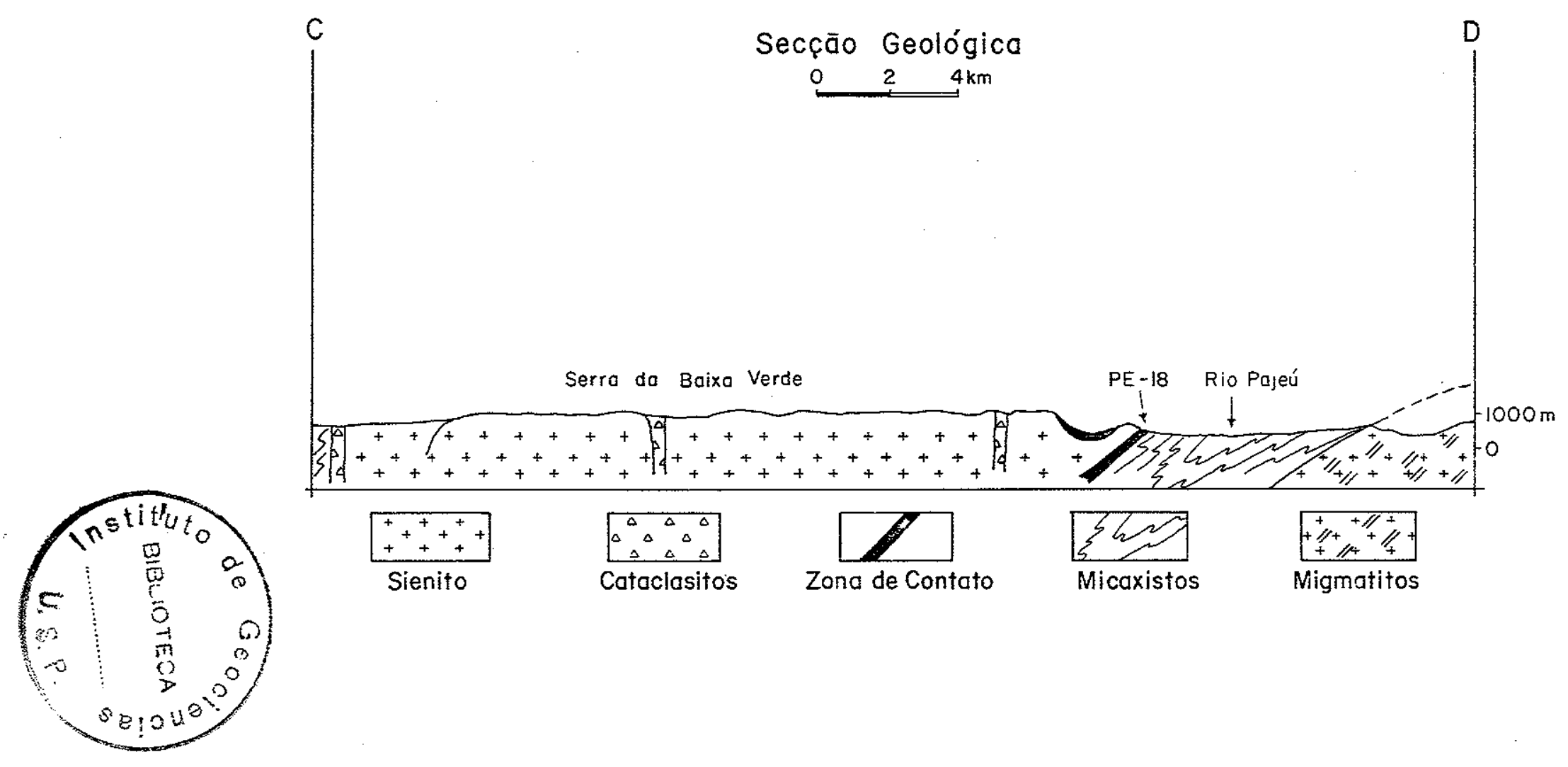

